\title{
Changes in Heart Transplant Recipients That Parallel the Personalities of Their Donors
}

\author{
Paul Pearsall, Ph.D. \\ University of Hawaii \\ Gary E. R. Schwartz, Ph.D. \\ Linda G. S. Russek, Ph.D. \\ University of Arizona
}

\begin{abstract}
It is generally assumed that learning is restricted to neural and immune systems. However, the systemic memory hypothesis predicts that all dynamical systems that contain recurrent feedback loops store information and energy to various degrees. Sensitive transplant patients may evidence personal changes that parallel the history of their donors. The objective of this study was to evaluate whether changes following heart transplant surgery parallel the history of the donors. We conducted open-ended interviews with volunteer transplant recipients, recipient families or friends, and donor families or friends, in hospitals in various parts of the country. Patients included ten recipients who had received heart or heart-lung transplants. Main outcome measures were transcripts of audiotaped interviews quoted verbatim. Two to 5 parallels per case were observed between changes following surgery and the histories of the donors. Parallels included changes in food, music, art, sexual, recreational, and career preferences, as well as specific instances of perceptions of names and sensory experiences related to the donors. The incidence of recipient awareness of personal changes in cardiac transplant patients is unknown. The effects of the immunosuppressant drugs, stress of the surgery, and statistical coincidence are insufficient to explain the findings.
\end{abstract}

Paul Pearsall, Ph.D., is Clinical Professor in the Department of Nursing at the University of Hawaii at Manoa, and President and Chief Executive Officer of Hoalo Ho [To Reawaken] in Honolulu, Hawaii.

Gary E. R. Schwartz, Ph.D., is Professor of Psychology, Medicine, Neurology, and Psychiatry at the University of Arizona, where he is also Director of the Human Energy Systems Laboratory. Reprint requests should be addressed to Dr. Schwartz at the Department of Psychology, University of Arizona, Box 210068, Tucson, AZ 857210068 (E-mail: gschwart@u.arizona.edu).

Linda G. S. Russek, Ph.D. is Assistant Clinical Professor of Medicine at the University of Arizona. 
We suggest that cellular memory, possibly systemic memory, is a plausible explanation for these parallels.

KEY WORDS: heart transplant; personality change; cellular memory; alternative medicine; energy medicine; systemic memory.

It is generally assumed that learning involves primarily the nervous system and, secondarily, the immune system. But if those systems were the sole repository of memory, then patients receiving peripheral organ transplants should not experience personality changes that parallel those of donors they have never met. Explanations that have been offered for personality changes observed following transplants include effects of the immunosuppressant drugs, psychosocial stress, and preexisting psychopathology of the recipients (Kuhn, Myers, Brennan, Davis, Lippman, Gray, and Pool, 1988; Lunde, 1967; Mai, 1986).

However, living systems theory explicitly posits that all living cells possess "memory" and "decider" functional subsystems within them (Miller, 1978). Moreover, the recent integration of systems theory with the concept of energy (termed dynamical energy systems theory) provides compelling logic that leads to the prediction that all dynamical systems store information and energy to various degrees (Schwartz and Russek, 1997, 1998a, 1998b). The systemic memory mechanism provides a plausible explanation for the evolution of emergent (novel) systemic properties through recurrent feedback interactions-that is, the nonlinear circulation of information and energy that reflects the ongoing interactions of the components in a complex, dynamic network. Recurrent feedback loops exist in all atomic, molecular, and cellular systems. Hence, evidence for atomic systemic memory, molecular systemic memory, and cellular systemic memory should be found in these systems.

The systemic memory mechanism has been applied to a variety of controversial and seemingly anomalous observations in complementary and alternative medicine, including homeopathy (Schwartz and Russek, 1998c). It also makes new predictions. One prediction is that sensitive recipients of organ transplant can experience aspects of the donor's personal history stored in the transplanted tissues.

In 1997, Claire Sylvia published a book describing the apparent personality changes she experienced after receiving a heart and lung transplant at Yale-New Haven Hospital in 1988 (Sylvia and Novak, 1997). She reported noticing that various attitudes, habits, and tastes 
changed following her surgery. She had inexplicable cravings for foods she previously disliked. For example, though she was a healthconscious dancer and choreographer, upon leaving the hospital she had an uncontrollable urge to go to a Kentucky Fried Chicken restaurant and order chicken nuggets, a food she never ate. Sylvia found herself drawn toward cool colors and no longer dressed in the bright reds and oranges she used to prefer. She began behaving with an aggressiveness and impetuosity that was uncharacteristic of her, but turned out to be similar to the personality of her donor. Interestingly, uneaten Kentucky Fried Chicken nuggets were found in the jacket of the young man when he was killed.

Sylvia's co-author, William Novak, sought opinions about the plausibility of cellular memory. In response, Paul Pearsall proposed that the immunosuppressant drugs could conceivably lower the threshold for patients to register cellular memories potentially stored in the transplanted organs (Pearsall, 1998; Sylvia and Novak, 1997); and Gary Schwartz and Linda Russek proposed that the rejection process might not only reflect the rejection of the material comprising the cells, but also the systemic information and energy stored within the cells as well (Schwartz and Russek, 1998b, 1998c; Sylvia and Novak, 1997). Sylvia was unique because she received a substantial amount of new tissue (heart and lungs), she was health-conscious, and she was emotionally open and sensitive. Invoking William James' aphorism that 'If you wish to upset the law that all crows are black, you mustn't seek to show that no crows are; it is enough if you prove one single crow to be white" (James, 1897, p. 5), Schwartz and Russek (1998b) proposed that Claire Sylvia might be the "white crow" of cellular systemic memory.

The present paper reports key observations from ten representative cases of transplant recipients who were open to sharing experiences of personal changes following their operations. Their experiences are consistent with the systemic memory prediction.

\section{Cases}

To protect the privacy of the donors' families, recipients and their families, physicians, and hospitals, donors and recipients are referred to below by number, except when their first names were mentioned by family members or friends in the transcripts. All recipients and family members or friends of the donors were interviewed and audiotaped by 
Pearsall. The transcripts were examined by Schwartz and Russek and selected for inclusion in this report.

Each of the ten cases includes a donor family member's report or its equivalent, a recipient's report or its equivalent, and a recipient family member's or friend's report. Donor family members, recipients, and recipient family members or friends are quoted directly from the transcripts. Personal opinions, including controversial content, are reported verbatim. Each case includes two to five sample parallels between the donors and changes observed in the recipients following transplant surgery.

\section{Case 1}

The donor was an 18-year-old boy killed in an automobile accident. The recipient was an 18-year-old-girl diagnosed with endocarditis and subsequent heart failure. The donor's father, a psychiatrist, reported:

My son always wrote poetry. We had waited more than a year to clean out his room after he died. We found a book of poems he had never shown us, and we've never told anyone about them. One of them has left us shaken emotionally and spiritually. It spoke of his seeing his own sudden death. He was a musician too, and we found a song he titled "Danny, My Heart is Yours." The words are about how my son felt he was destined to die and give his heart to someone. He had decided to donate his organs when he was 12 years old. We thought it was quite strong, but we thought they were talking about it in school. When we met his recipient, we were so ... we didn't know like what it was. We don't know now. We just don't know.

The recipient reported:

When they showed me pictures of their son, I knew him directly. I would have picked him out anywhere. He's in me. I know he is in me and he is in love with me. He was always my lover, maybe in another time somewhere. How could he know years before he died that he would die and give his heart to me? How would he know my name is Danielle? And then, when they played me some of his music, I could finish the phrases of his songs. I could never play before, but after my transplant, I began to love music. I felt it in my heart. My heart had to play it. I told my mom I wanted to take guitar lessons, the same instrument Paul [the donor] had played. His song is in me. I feel it a lot at night and it's like Paul is serenading me.

The recipient's father reported:

My daughter, she was what you say ... a hell raiser. Until she got sick, they say from a dentist they think, she was the wild one. Then, she 
became quite quiet. I think it was her illness, but she said she felt more energy, not less. She said she wanted to play an instrument and she wanted to sing. When she wrote her first song, she sang about her new heart as her lover's heart. She said her lover had come to save her life.

\section{Case 2}

The donor was a 16-month-old boy who drowned in a bathtub. The recipient was a 7-month-old boy diagnosed with tetralogy of Fallot, a syndrome involving a hole in the ventricular septum, displacement of the aorta, pulmonary stenosis, and thickening of the right ventricle. The donor's mother, a physician, reported:

The first thing is that I could more than hear Jerry's [her son, the donor] heart. I could feel it in me. When Carter [the recipient] first saw me, he ran to me and pushed his nose against me and rubbed and rubbed it. It was just exactly what we did with Jerry. Jerry and Carter's heart is $\mathbf{5}$ years old now, but Carter's eyes were Jerry's eyes. When he hugged me, I could feel my son. I mean I could feel him, not just symbolically. He was there. I felt his energy.

I'm a doctor. I'm trained to be a keen observer and have always been a natural born skeptic. But this was real. I know people will say that I need to believe my son's spirit is alive, and perhaps I do. But I felt it. My husband and my father felt it. And I swear to you, and you can ask my mother, Carter said the same baby-talk words that Jerry said. Carter is 6, but he was talking Jerry's baby talk and playing with my nose just like Jerry did.

We stayed with the [recipient family] that night. In the middle of the night, Carter came in and asked to sleep with my husband and me. He cuddled up between us exactly like Jerry did, and we began to cry. Carter told us not to cry because Jerry said everything was okay. My husband and I, our parents, and those who really knew Jerry have no doubt. Our son's heart contains much of our son and beats in Carter's chest. On some level, our son is still alive.

The recipient's mother reported:

I saw Carter go to her [the donor's mother]. He never does that. He is very, very shy, but he went to her just like he used to run to me when he was a baby. When he whispered "It's okay, Mama," I broke down. He called her Mother, or maybe it was Jerry's heart talking. And one more thing that got to us. We found out talking to Jerry's mom that Jerry had mild cerebral palsy, mostly on his left side. Carter has stiffness and some shaking on that same side. He never did as a baby and it only showed up after the transplant. The doctors say it's probably something to do with his medical condition, but I really think there's more to it. 
One more thing I'd like you to know about. When we went to church together, Carter had never met Jerry's father. We came late and Jerry's dad was sitting with a group of people in the middle of the congregation. Carter let go of my hand and ran right to that man. He climbed on his lap, hugged him, and said "Daddy." We were flabbergasted. How could he have known him? Why did he call him Dad? He never did things like that. He would never let go of my hand in church and never run to a stranger. When I asked him why he did it, he said he didn't. He said Jerry did and he went with him.

\section{Case 3}

The donor was a 24-year-old female automobile accident victim. The recipient was a 25-year-old male graduate student suffering from cystic fibrosis who received a heart-lung transplant. The donor's sister reported:

My sister was a very sensual person. Her one love was painting. She was on her way to her first solo showing at a tiny art shop when a drunk plowed into her. It's a lesbian art store that supports gay artists. My sister was not really very "out" about it, but she was gay. She said her landscape paintings were really representations of the mother or woman figure. She would look at a naked woman model and paint a landscape from that! Can you imagine? She was gifted.

\section{The recipient reported:}

I never told anyone at first, but I thought having a woman's heart would make me gay. Since my surgery, I've been hornier than ever, and women just seem to look even more erotic and sensual, so I thought I might have gotten internal transsexual surgery. My doctor told me it was just my new energy and lease on life that made me feel that way, but I'm different. I know I'm different. I make love like I know exactly how the woman's body feels and responds-almost as if it is my body. I have the same body, but I still think I've got a woman's way of thinking about sex now.

The recipient's girlfriend reported:

He's a much better lover now. Of course, he was weaker before, but it's not that. He's like, I mean he just knows my body as well as I do. He wants to cuddle, hold, and take a lot of time. Before he was a good lover, but not like this. It's just different. He wants to hug all the time and go shopping. My God, he never wanted to shop. And you know what? He carries a purse now. His purse! He slings it over his shoulder and calls it his bag, but it's a purse. He hates it when I say that, but going to the mall with him is like going with one of the girls. And one more thing: he loves to go to museums. He would never, absolutely never, do 
that. Now he would go every week. Sometimes he stands for minutes and looks at a painting without talking. He loves landscapes and just stares. Sometimes I just leave him there and come back later.

\section{Case 4}

The donor was a 17-year-old African-American male student, a victim of a drive-by shooting. The recipient was a 47-year-old Caucasian male foundry worker diagnosed with aortic stenosis. The donor's mother reported:

Our son was walking to violin class when he was hit. Nobody knows where the bullet came from, but it just hit him and he fell. He died right there on the street hugging his violin case. He loved music and his teachers said he had a real thing for it. He would listen to music and play along with it. I think he would have been at Carnegie Hall someday, but the other kids always made fun of the music he liked.

\section{The recipient reported:}

I'm real sad and all for the guy who died and gave me his heart, but I really have trouble with the fact that he was black. I'm not a racist, mind you, not at all. Most of [my] friends at the plant are black guys. But the idea that there is a black heart in a white body seems really... well, I. don't know. I told my wife that I thought my penis might grow to a black man's size. They say black men have larger penises, but I don't know for sure. After we have sex, I sometimes feel guilty because a black man made love to my wife, but I don't really think that seriously. I can tell you one thing, though. I used to hate classical music, but now I love it. So I know it's not my new heart, because a black guy from the hood wouldn't be into that. Now it calms my heart. I play it all the time. I more than like it. I play it all the time. I didn't tell any of the guys on the line that I have a black heart, but I think about it a lot.

The recipient's wife reported:

He was more than concerned about the idea when he heard it was a black man's heart. He actually asked me if he could ask the doctor for a white heart when one came up. He's no Archie Bunker, but he's close to it. And he would kill me if he knew I told you this, but for the first time, he's invited his black friends over from work. It's like he doesn't see their color anymore, even though he still talks about it sometimes. He seems more comfortable and at ease with these black guys, but he's not aware of it. And more thing I should say. He's driving me nuts with the classical music. He doesn't know the name of one song and never, never listened to it before. Now, he sits for hours and listens to 
it. He even whistles classical music songs that he could never know. How does he know them? You'd think he'd like rap music or something because of his black heart.

\section{Case 5}

The donor was a 19-year-old woman killed in an automobile accident. The recipient was a 29-year-old woman diagnosed with cardiomyopathy secondary to endocarditis. The donor's mother reported:

My Sara was the most loving girl. She owned and operated her own health food restaurant and scolded me constantly about not being a vegetarian. She was a great kid-wild, but great. She was into the free love thing and had a different man in her life every few months. She was "man crazy" when she was a little girl, and it never stopped. She was able to write some notes to me when she was dying. She was so out of it, but she kept saying how she could feel the impact of the car hitting them. She said she could feel it going through her body.

The recipient reported:

You can tell people about this if you want to, but it will make you sound crazy. When I got my new heart, two things happened to me. First, almost every night and still sometimes now, I actually feel the accident my donor had. I can feel the impact in my chest. It slams into me, but my doctor said everything looks fine. Also, I hate meat now. I can't stand it. I was McDonald's biggest moneymaker, and now meat makes me throw up. Actually, when I even smell it, my heart starts to race. But that's not a big deal. My doctor said that's just due to my medicines. I couldn't tell him, but what really bothers me is that I'm engaged to be married now. He's a great guy and we love each other. The sex is terrific. The problem is, I'm gay. At least, I thought I was. After my transplant, I'm not. ... I don't think anyway.... I'm sort of semi- or confused-gay. Women still seem attractive to me, but my boyfriend turns me on. Women don't. I have absolutely no desire to be with a woman. I think I got a gender transplant.

\section{The recipient's brother reported:}

Susie's straight now. I mean it seriously. She was gay and now her new heart made her straight. She threw out all her books and stuff about gay politics and never talks about it any more. She was really militant about it before. She holds hands and cuddles with Steven just like my girlfriend does with me. She talks girl talk with my girl friend, where before she would be lecturing about the evils of sexist men. And my sister, the Queen of the Big Mac, hates meat. She won't even have it in the house. 


\section{Case 6}

The donor was a 14-year-old girl injured in a gymnastics accident. The recipient was a 47-year-old man diagnosed with benign myxoma and cardiomyopathy. The donor's mother reported:

Look at her [showing picture]. My daughter was the picture of health. There wasn't an once of fat on her. She was a gymnast and her coach could lift her above his head with one hand. She was so excited about life that she would just hop and jump all the time like a kitten. She had some trouble with food, though. She would skip meals and, for a while, she was purging. I think they would call her a little anorexic. We took her to therapy about it, but she just wasn't much into food. And she had this silly little giggle when she got embarrassed. It sounded like a little bird.

The recipient reported:

I feel new again. I feel like a teenager. I actually feel giddy. I know it's just the energy of the new heart, but I really feel younger in every way, not just physically. I see the world that way. I'm really young at heart. I have this annoying tendency to giggle that drives my wife nuts. And there's something about food. I don't know what it is. I get hungry, but after I eat, I often feel nauseated and that it would help if I could throw up.

The recipient's brother reported:

Gus is a teenager. No doubt about that. He's a kid -or at least he thinks he's a kid. Even when we're bowling, he yells and jumps around like a fool. He's got this weird laugh now. It's a girl's laugh and we tell him that. He doesn't care. His appetite never did bounce back after the surgery. He's pretty much nauseated almost all the time. After Thanksgiving dinner-and he loved it-he went upstairs and vomited. We took him to the emergency room, but it wasn't anything to do with his new heart. They said it was probably a reaction to something in the meal. None of the rest of the family got sick, though. He's going to have to watch it. His doctor is concerned about his weight.

\section{Case 7}

The donor was a 3-year-old girl who drowned in the family pool. The recipient was a 9-year-old boy diagnosed with myocarditis and septal defect. The recipient's mother, who knew who the donor had been, reported:

He [the recipient] doesn't know who his donor was or how she died. We do. She drowned at her mother's boyfriend's house. Her mother and 
her boyfriend left her with a teenage babysitter who was on the phone when it happened. I never met her father, but the mother said they had a very ugly divorce and that the father never saw his daughter. She said she worked a lot of hours and wished she had spent more time with her. I think she feels pretty guilty about it all ... you know, the both of them sort of not appreciating their daughter until it was too late.

The recipient, who claimed not to know who the donor was, reported:

I talk to her sometimes. I can feel her in there. She seems very sad. She is very afraid. I tell her it's okay, but she is very afraid. She says she wishes that parents wouldn't throw away their children. I don't know why she would say that.

The recipient's mother further reported about the recipient:

Well, the one thing I notice most is that Jimmy is now deathly afraid of the water. He loved it before. We live on a lake and he won't go out in the backyard. He keeps closing and locking the back doorwalls. He says he's afraid of the water and doesn't know why. He won't talk about it.

\section{Case 8}

The donor was a 19-year-old woman who suffered a broken neck in dance class. The recipient was a 19-year-old woman diagnosed with cardiomyopathy. The donor's mother reported:

We've met Angela [the recipient], and she is the image of our daughter. They could almost be twins. They're both bright girls; I mean, my daughter was bright, too. She wanted to be an actress, but we thought she had too much academic potential for that. Her father is a doctor and really wanted her to follow in his footsteps.

The donor's father reported:

Stacy [his daughter, the donor] was extremely bright. It's so tragic. She would have made an outstanding physician, but she wanted to dance and sing. That's how she died. She fell in dance class. We always argued good-naturedly about how disappointed I would be if she went to Hollywood instead of Harvard. I hope she knew I just wanted her to be happy.

The recipient reported:

I think of her as my sister. I think we must have been sisters in a former life. I only know my donor was a girl my age, but it's more than that. I talk to her at night or when I'm sad. I feel her answering me. 
I can feel it in my chest. I put my left hand there and press it with my right. It's like I can connect with her. Sometimes she seems sad. I think she wanted to be a nurse or something, but other times it's like she wanted to be on Broadway. I think she wanted to be on Broadway more. I want to be a nurse, but I could be a doctor too. I hope she will be happy, because she will always be my angel, my sister in my chest. I carry my angel with me everywhere.

The recipient's mother reported:

We can sometimes hear her talking to her heart. It's like a "Dear Diary" thing. She puts her hand on her chest and talks to who she thinks her donor is. Once, we found her holding a stethoscope to her chest to try to hear her new heart. I think she still does that sometimes. And the only other thing is that she really wants to go to medical school now. She never wanted to do that before, but that's because I don't think she thought she would live. She's already changed her college classes.

\section{Case 9}

The donor was a 3-year-old boy who fell from an apartment window. The recipient was a 5-year-old boy with septal defect and cardiomyopathy. The donor's mother reported:

It was uncanny. When I met the family and Daryl [the recipient] at the transplant meeting, I broke into tears. We went up to the giving tree where you hand a token symbolizing your donor. I was already crying when my husband told me to look at the table we were passing. It was the [recipient's family] with Daryl sitting there. I knew it right away. Daryl smiled at me exactly like Timmy [her son, the donor] did. After we talked for hours with Daryl's parents, we were comforted. It somehow just didn't seem strange at all after a while. When we heard that Daryl had made up the name Timmy and got his age right, we began to cry. But they were tears of relief because we knew that Timmy's spirit was alive.

\section{The recipient reported:}

I gave the boy a name. He's younger than me and I call him Timmy. He's just a little kid. He's a little brother like about half my age. He got hurt bad when he fell down. He likes Power Rangers a lot, I think, just like I used to. I don't like them anymore, though. I like Tim Allen on "Tool Time," so I called him Tim. I wonder where my old heart went, too. I sort of miss it. It was broken, but it took care of me for a while.

The recipient's father reported:

Daryl never knew the name of his donor or his age. We didn't know, either, until recently. We just learned that the boy who died had fallen 
from a window. We didn't even know his age until now. Daryl had it about right. Probably just a lucky guess or something, but he got it right. What is spooky, though, is that he not only got the age right and some idea of how he died, he got the name right. The boy's name was Thomas, but for some reason his immediate family called him "Tim."

The recipient's mother added:

Are you going to tell him the real Twilight Zone thing? Timmy fell trying to reach a Power Ranger toy that had fallen on the ledge of the window. Daryl won't even touch his Power Rangers any more.

\section{Case 10}

The donor was a 34-year-old police officer shot attempting to arrest a drug dealer. The recipient was a 56-year-old college professor diagnosed with atherosclerosis and ischemic heart disease. The donor's wife reported:

When I met Ben and Casey [the recipient and his wife], I almost collapsed. First, it was a remarkable feeling seeing the man with my husband's heart in his chest. I think I could almost see Carl ther husband, the donor] in Ben's eyes. When I asked how Ben felt, I think I was really trying to ask Carl how he was. I wouldn't say that to them, but I wish I could have touched Ben's chest and talked to my husband's heart.

What really bothers me, though, is when Casey said offhandedly that the only real side effect of Ben's surgery was flashes of light in his face. That's exactly how Carl died. The bastard shot him right in the face. The last thing he must have seen is a terrible flash. They never caught the guy, but they think they know who it is. I've seen the drawing of his face. The guy has long hair, deep eyes, a beard, and this real calm look. He looks sort of like some of the pictures of Jesus.

\section{The recipient reported:}

If you promise you won't tell anyone my name, I'll tell you what I've not told any of my doctors. Only my wife knows. I only knew that my donor was a 34-year-old, very healthy guy. A few weeks after I got my heart, I began to have dreams. I would see a flash of light right in my face and my face gets real, real hot. It actually burns. Just before that time, I would get a glimpse of Jesus. I've had these dreams and now daydreams ever since: Jesus and then a flash. That's the only thing I can say is something different, other than feeling really good for the first time in my life.

The recipient's wife reported:

I'm very, very glad you asked him about his transplant. He is more bothered than he'll tell you about these flashes. He says he sees Jesus 
and then a blind flash. He told the doctors about the flashes, but not Jesus. They said it's probably a side effect of the medications, but, God, we wish they would stop.

\section{Discussion}

The set of cases reported here are representative of more than 74 transplant cases, 23 of whom were heart transplants, that were brought to Pearsall's attention over the past 10 years (Pearsall, 1998). Because the cases were collected sporadically in clinical situations, it is not possible to calculate the percent of patients who reported personality changes that did or did not parallel the donors' to various degrees. The present report provides theoretical and empirical justification for conducting a controlled comprehensive study.

Historically, transplant recipients have been reluctant to share such experiences with their physicians, and in many cases, even with their families and friends. Moreover, the prevailing belief that memories are stored primarily in the nervous system and secondarily in the immune system would decrease the likelihood that transplant recipients would be open to receiving cellular memories from the transplanted organs in the first place. The same belief would decrease the likelihood that family members and friends, as well as surgeons and healthcare providers in general, would be open to hearing about cellular memories from transplant recipients. For these reasons, it is likely that personality changes that parallel the donors' personalities would be underreported.

Case 4 illustrates this point. When a 47-year-old Caucasian foundry worker received the heart of a 17-year-old African-American student, he presumed that the donor would have preferred rap music. Hence, he dismissed the idea that his new radical change in preference for classical music could have come from the heart of the donor. However, unbeknownst to the recipient, the donor actually loved classical music, and died "hugging his violin case" on the way to his violin class.

Schwartz and Russek recently interviewed another patient who received a heart transplant and experienced personality changes, not included in the series above because the donor family has not yet been interviewed. This patient received a woman's heart, and his many personality changes included a passion for the color pink, a color he disliked prior to surgery, and a preference for perfumes, which prior to his surgery he could not tolerate and would not allow his wife to wear. He currently bathes and wears feminine fragrances. His daughters tease him, and he is afraid to share these experiences with his doctors. 
He shared them with Schwartz and Russek because he learned they were open to these changes and would help him discover if they were related to the donor. (Efforts are currently underway to contact the donor's family.) His case is interesting because he was pronounced dead and revived twice prior to his transplant. He had a near-death experience that, according to the patient and his wife, transformed him and led him to be more open.

Recipients may vary in their openness to receiving cellular information, as well as in their clarity in experiencing and reporting changes. One unanswered question is whether recipients have any control over this; that is, whether all recipients would experience personality changes if they were open to it. This is an important question that can be addressed in future research. It is plausible that more individuals would be able to retrieve information if they were encouraged to be open and receive the information. Hypnosis could be considered as a possible clinical research tool.

The cases reported here are unusual (but not unique) in that recipients observed clear changes that were subsequently verified by family members or friends. Moreover, in each case, information about the donors was specifically verified from donor family members or friends. In each case, personal changes in the recipients preceded any contact with the donor's family members or friends.

The recipients reported here would not receive psychiatric diagnoses. They were not suffering from extreme depression or anxiety, though some reported anxiety about their experiences. Case 10 illustrates this feature: a recipient was a college professor who experienced dreams not only of white flashes in his face but, just before the flash, he sometimes "would get a glimpse of Jesus." Fearful of this potential hallucination and its possible diagnostic significance, he did not share this information with his doctors, though he did tell them about the flashes. The donor was a police officer who was shot in the face attempting to arrest a drug dealer. According to the donor's wife, "They never caught the guy, but they think they know who it is.... He looks sort of like some of the pictures of Jesus."

Can such reports be explained by statistical coincidence? The parallels in names reported in some of the cases, such as case 1 (Danny and Danielle), could potentially be explained as coincidences. In case 9, the young recipient's choice of the name Tim for the donor he never met may have been related to his personal affinity for actor Tim Allen. However, the statistical coincidence explanation is strained in this case by the recipient's additional perception that " $\mathrm{He}$ [the donor] likes Power 
Rangers a lot, I think, just like I used to. I don't like them anymore though." The donor purportedly died "trying to reach a Power Ranger toy that had fallen on the ledge of the window." The total set of findings spanning the 10 cases appear too coincidental to support the statistical coincidence hypothesis.

Future research is necessary to investigate the recipient-donor coincidence phenomenon systematically. Research is underway at the University of Arizona on a sample of more than 300 transplant patients to estimate the incidence of such coincidences using semistructured interviews and systematic questions. In addition, a subset of the transplant patients is being monitored physiologically to examine biophysical measures of heart-brain synchrony (Song, Schwartz, and Russek, 1998). The research is testing predictions derived from dynamical energy systems theory applied to the heart. Termed energy cardiology, the basic hypothesis is that information and energy are transmitted electromagnetically between the brain and heart, and that through electromagnetic resonance, the brain may process information derived from the donor's heart (Russek and Schwartz, 1994, 1996). Systemic memory is only one possible cellular memory mechanism, and other mechanisms, such as microtubule memory, which may also involve the systemic memory process, should be considered (Hameroff and Penrose, 1996), as well as other forms of energetic communication (Tiller, 1997).

Pearsall (1988) has observed informally that in addition to heart recipients, kidney, liver, and other organ recipients also indicated changes in sense of smell, food preference, and emotional factors. However, these changes were usually transitory and could be associated with medications and other factors of transplantation. The findings for heart transplants appear more robust and more strongly associated with the donor's history.

If future research documents evidence for cellular memory in transplant patients, the theoretical, clinical, and ethical implications are vast (Schwartz and Russek, 1999). The present findings are reported with the hope that they will stimulate future research to examine the hypothesis seriously.

\section{Acknowledgments}

The authors wish to thank the families of the donors, the recipients, and the families of the recipients, who bravely shared their stories and 
graciously agreed to have them reported; and the anonymous reviewers of this manuscript for their constructive feedback. We dedicate this paper to the memories of donors, and to the memories of Frank Pearsall, Howard Schwartz, and Henry I. Russek, our fathers.

\section{References}

Hameroff, S. R, and Penrose, R. (1996). Orchestrated reduction of quantum coherence in brain microtubules: A model for consciousness. In Hameroff, S. R., Kaszniak, A. W., and Scott, A. C. (Eds.), Toward a science of consciousness: The first Tucson discussions and debates (pp. 507-540). Cambridge, MA: Massachusetts Institute of Technology Press.

James, W. (1897). Presidential address. Proceedings of the Society for Psychical Research, $12,2-10$.

Kuhn, W. F., Myers, B., Brennan, A. F., Davis, M. H., Lippmann, S. B., Gray, L. A., and Pool, G. E. (1988). Psychopathology in heart transplant candidates. Journal of Heart Transplantation, 7, 223-226.

Lunde, D. T. (1967). Psychiatric complications of heart transplants. American Journal of Psychiatry, 124, 1190-1195.

Mai, F. M. (1986). Graft and donor denial in heart transplant recipients. American Journal of Psychiatry, 143, 1159-1161.

Miller, J. G. (1978). Living systems. New York, NY: McGraw-Hill.

Pearsall, P. (1998). The heart's code: Tapping the wisdom and power of our heart energy. The new findings about cellular memories and their role in the mind/body/spirit connection. New York, NY: Broadway Books.

Russek, L. R. S., and Schwartz, G. E. R. (1994). Interpersonal heart-brain registration and the perception of parental love: A 42-year follow-up of the Harvard Mastery of Stress Study. Subtle Energies, 5, 195-208.

Russek, L. G. S., and Schwartz, G. E. R. (1996). Energy cardiology: A dynamical energy systems approach for integrating conventional and alternative medicine. Advances: The Journal of Mind-Body Health, 12(4), 4-24.

Schwartz, G. E. R., and Russek, L. G. S. (1997). Dynamical energy systems and modern physics: Fostering the science and spirit of complimentary and alternative medicine. Alternative Therapies in Health and Medicine, 3(3), 46-56.

Schwartz, G. E. R., and Russek, L. G. S. (1998a). Do all dynamical systems have memory? Implications of the systemic memory hypothesis for science and society. In Pribram, K. H. (Ed.), Brain and values: Is a biological science of values possible? (pp. 259-273). Hillsdale, NJ: Lawrence Erlbaum Associates.

Schwartz, G. E. R., and Russek, L. G. S. (1998b). The origin of holism and memory in nature: The systemic memory hypothesis. Frontier Perspectives, 7(2), 23-30.

Schwartz, G. E. R., and Russek, L. G. S. (1998c). The plausibility of homeopathy: The systemic memory mechanism. Integrative Medicine, 1(2), 53-60.

Schwartz, G. E. R., and Russek, L. G. S. (1999). The living energy universe. Charlottesville, VA: Hampton Roads.

Song, L. Z. Y. X., Schwartz, G. E. R., and Russek, L. G. S. (1998). Heart-focused attention and heart-brain synchronization: Energetic and physiological mechanisms. Alternative Therapies in Health and Medicine, 4(5), 44-63.

Sylvia, C., and Novak, W. (1997). A change of heart. New York, NY: Warner Books.

Tiller, W. A. (1997). Science and human transformation: Subtle energies, intentionality and consciousness. Walnut Creek, CA: Pavior. 